\title{
Isotopic Studies on the Metabolism of Protein and Ribonucleic Acid of Mytilus Gill
}

\author{
Kenzo Taguchi and Taiji Schimizu \\ Laboratory of Radioisotope Research, Niigata University, Niigata \\ Received September 24, 1966
}

\begin{abstract}
The amount of carbons in the metabolic pool for protein synthesis and the amount of carbons in the pool consumed for the metabolism other than protein synthesis were calculated to be $7.56 \mu_{\mathrm{g}} / 0.5 \mathrm{~g}$-gill and $3.94 \mu_{\mathrm{g}} / \mathrm{h} / 0.5 \mathrm{~g}$-gill, respectively. The amount of carbons in the pool for RNA synthesis and the amount of carbons in the pool consumed for the metabolism other than RNA synthesis were calculated to be $9.85 \times 10^{-1} \mu_{\mathrm{g}} / \mathrm{g}$-gill and $1.32 \times 10^{-2}$

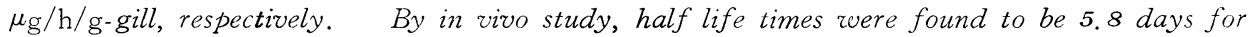
gill-protein, 3.96 days for midgut-protein, 2.6 days for gill-RNA and 10.6 days for midgutRNA. In the case of gill, the proteins about mucus glands inside of a ciliated groove were very active metabolically.
\end{abstract}

Since the cilia on the gills of Mytilus are capable of expending energy for prolonged periods after excision from the animals it follows that the substance from which this energy is derived must be present in the cells in relatively large amounts. Gray ${ }^{1)}$ suggested that glycoprotein forms the source of ciliary energy in Mytilus. Usuki ${ }^{2,3)}$ has concluded that the ciliary movement of oyster gills links closely with the oxidative metabolism of glycogen. $\mathrm{We}^{4)}$ reported that the ciliary movement of Mytilus gills relates with the metabolism of glycogen in the intercellular spaces abutting on the ciliated cells inside of a ciliated groove. The most obvious physiological parallels to the spontaneous rythems so characteristic of cilia are presented by cardiac muscle cells in vertebrates and by certain locomotory muscles in the invertebrates. This similarity between muscles and gills made us study the problems of protein metabolism of gills.

\section{Experimental}

1.1 In vitro incorporation of ${ }^{14} \mathrm{C}$-glycine in to the proteins

The gills of Mytilus edulis, L. were excised from the ventral margin of the gill lamellae and $0.5 \mathrm{~g}$ of gills was taken into a Warburg flask and incubated in the artificial sea water with $5 \mu \mathrm{Ci}$ of ${ }^{14} \mathrm{C}$-2-glycine (Daiichi Pure Chemicals Co., Ltd., $9.9 \mathrm{mCi} / \mathrm{mM}$ ) at $25^{\circ} \mathrm{C}$.
The composition of the artificial sea water was previously reported ${ }^{4}$. The $\mathrm{pH}$ of the artificial sea water was adjusted to 7.8 with Tris-buffer and the total volume of the medium was adjusted to $2 \mathrm{~m} l$. Immediately after incubation, the flask was inserted into an icewater and $3.8 \mathrm{mg}$ of ${ }^{12} \mathrm{C}$-glycine was added to the medium to stop the reaction. Then $2 \mathrm{~m} l$ of $0.9 \%$ saline was added to it and the content of flask was centrifuged. The gills precipitated were washed again with $2 \mathrm{~m} l$ of $0.9 \%$ saline containing $3.8 \mathrm{mg}$ of ${ }^{12} \mathrm{C}$-glycine and homogenized with $0.9 \%$ saline. To the homogenate, $2 \mathrm{~m} l$ of cold $12 \%$ perchloric acid (PCA) was added and the mixture was allowed to stand for $10 \mathrm{~min}$. The precipitated material was centrifuged down and washed with $2 \mathrm{~m} l$ of cold $6 \%$ PCA. Each PCA extract was combined and neutralized with $20 \% \mathrm{KOH}$ to phenolphthalein. After standing for at least 2 hours, the resulting precipitates were centrifuged down. A suitable portion of the supernatant solution was taken as a sample of the free intracellular ${ }^{14} \mathrm{C}$. The precipitated proteins were treated with ethanol and hot ethanol-ether (3:1) to remove lipids.

$1 \cdot 2$ In vitro incorporation of ${ }^{14} \mathrm{C}$-orotic acid into ribonucleic acid (RNA)

One $\mathrm{g}$ of gills was incubated with $4 \mu \mathrm{Ci}$ of ${ }^{14} \mathrm{C}$-6-orotic acid (Daiichi Pure Chemicals Co., Ltd., $21.5 \mathrm{mCi} / \mathrm{m} M$ ) as described above. The 
total volume of the medium was $4 \mathrm{ml}$. After incubation the gills were taken out and homogenized with $4 \mathrm{~m} l$ of $0.15 M$ saline- $0.001 M$ EDTA (pH 8.0). The volume of the homogenate was made to $10 \mathrm{~m} l$ with $0.15 M$ saline- 0.001 $M$ EDTA (pH 8.0), and $0.1 \mathrm{~m} l$ of $2 \%$ sodium dodecyl sulfate was added to the homogenate. The mixture was heated at $60^{\circ} \mathrm{C}$ for $10 \mathrm{~min}$ with occasional shaking. After cooling to room temperature, solid sodium chloride was added with vigorous stirring to it to a final concentration of $0.4 \mathrm{M}$. The turbid solution was freed of proteins by shaking it with one volume of a 9:1 mixture of chloroform-octanol for $30 \mathrm{~min}$, followed by centrifugation at 4000 rpm for $15 \mathrm{~min}$. To the upper water-layer, 2 volumes of ethanol were added to precipitate RNA. RNA obtained was washed with 70,80 and $98 \%$ ethanol successively to remove any salts. The free intracellular ${ }^{1+} \mathrm{C}$ sample was prepared from another incubation experiment. The preparation method was as same as in the case of ${ }^{14} \mathrm{C}$-glycine but $3 \mathrm{mg}$ of ${ }^{12} \mathrm{C}$-orotic acid instead of ${ }^{12} \mathrm{C}$-glycine was added to the medium after incubation.

\subsection{In vivo incorporation of ${ }^{14} \mathrm{C}$-leucine into the proteins}

To adductor muscle of Mytilus, $2 \mu \mathrm{Ci} \quad(0.2$ $\mathrm{ml}$ ) of ${ }^{14} \mathrm{C}$-L-leucine (u) (Radiochemical Centre, Amersham, $100 \mathrm{mCi} / \mathrm{m} M$ ) was injected. The gills and midgut were excised and proteins were isolated as described above. Some pieces of gills of the animal 2 days after the injection were fixed in diluted formaldehyde for 2 hours and then embedded in paraffin and sectioned at $8 \mu$ in thickness. After deparaffinization, the sections were covered with a thin film of celloidine. Gill sections thus treated were taken for autoradiography by the inverting method using the emulsion of ET2E plate for stripping method (Fuji Photo Film Co., Ltd., Japan).

\subsection{In vivo incorporation of ${ }^{14} \mathrm{C}$-orotic acid into RNA}

To adductor muscle, $10 \mu \mathrm{Ci}(0.2 \mathrm{ml})$ of ${ }^{14} \mathrm{C}$ 6-orotic acid was injected. Gills and midgut were excised and RNAs were isolated as described above.

\section{$1 \cdot 5$ Measuring of ${ }^{14} \mathrm{C}$-activity}

Each sample prepared was dried on a metal dish under infrared rays. The dried material was weighed and its radioactivity was determined by a windowless gas-flow counter. Corrections were made for self-absorption from an empirically determined curve.

\section{Results}

$2 \cdot 1$ Time-course of ${ }^{14} \mathrm{C}$-glycine uptake by proteins in vitro

${ }^{14} \mathrm{C}$-glycine uptake by proteins at various incubation periods is shown in Table 1. The time-course of the incorporation is shown in Fig. 1. We have found empirically that the Table 1 The incorporation of ${ }^{14} \mathrm{C}$-glycine into gill protein

\begin{tabular}{|c|c|c|}
\hline \multirow{2}{*}{$\begin{array}{l}\text { Incubation } \\
\text { period (h) }\end{array}$} & \multicolumn{2}{|c|}{ Incorporation } \\
\hline & $\mathrm{cpm} / \mathrm{mg}$-protein & $\mu_{\mathrm{g}-{ }^{14} \mathrm{C} / \mathrm{mg}-}$ \\
\hline 0.5 & 227 & $4.15 \times 10^{-5}$ \\
\hline 1. 0 & 444 & $8.13 \times 10^{-5}$ \\
\hline 1. 5 & 556 & 1. $02 \times 10^{-4}$ \\
\hline 2. 0 & 617 & 1. $13 \times 10^{-4}$ \\
\hline
\end{tabular}

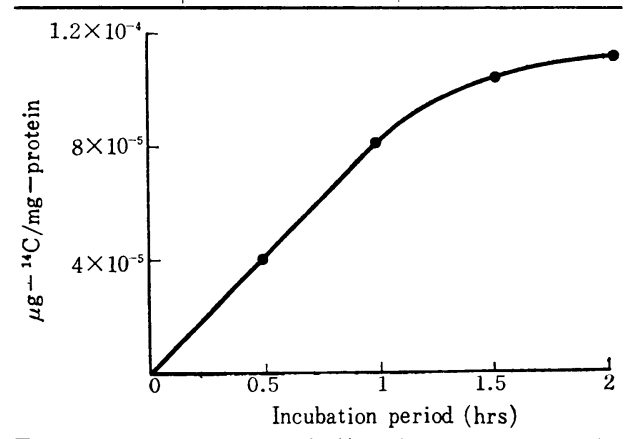

Fig. 1 Time curve of ${ }^{14} \mathrm{C}$-glycine uptake by gill protein.

incorporation of ${ }^{14} \mathrm{C}$ into proteins can be represented by Equation (1)

$$
I_{t}=1.155 \times 10^{-4} I_{0}\left(1-e^{-0.525 t}\right)
$$

where $I_{t}=\mu \mathrm{g}$ of ${ }^{14} \mathrm{C}$ incorporated into one $\mathrm{mg}$ of proteins after $t$ hour incubation of gills with ${ }^{14} \mathrm{C}$-glycine and $I_{0}=\mu \mathrm{g}$ of ${ }^{14} \mathrm{C}$ added in the medium $\left(I_{0}=1.098 \mu \mathrm{g}-{ }^{14} \mathrm{C}\right)$.

Because one $\mathrm{g}$ of gills contains $72 \mathrm{mg}$ of proteins as shown in Table 2 and one $\mu \mathrm{Ci}$ of ${ }^{14} \mathrm{C}$ corresponds with $1.2 \times 10^{6} \mathrm{cpm}$ with our counter, if glycine was taken up by proteins without decomposition, the amount of carbons consumed in the cells for the protein synthesis 


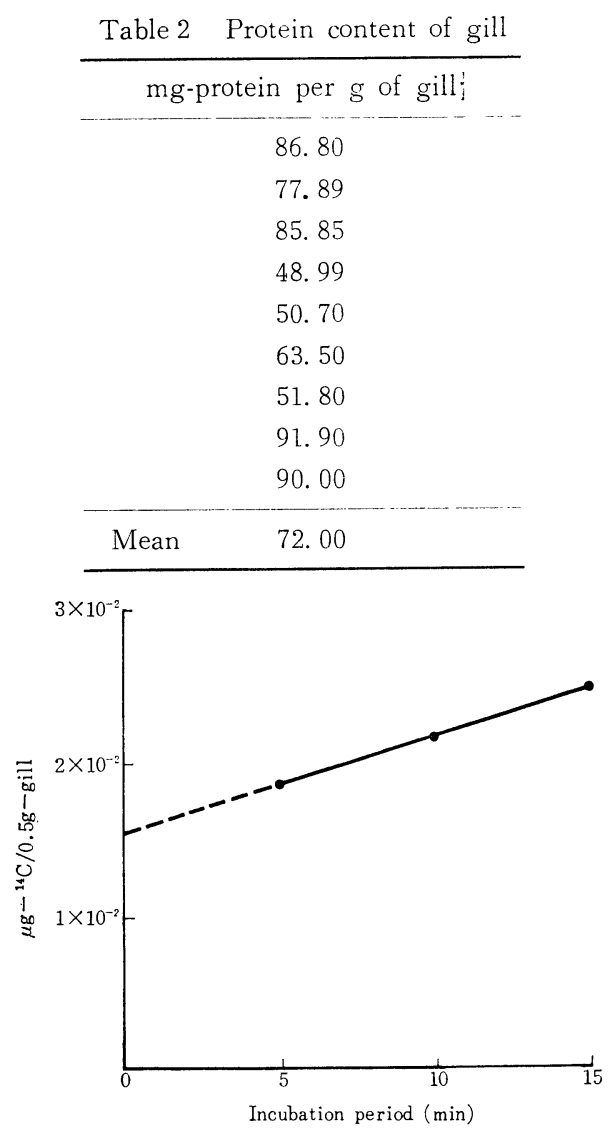

Fig. 2 Time curve of free intracellular ${ }^{14} \mathrm{C}$ content of the gill incubated with ${ }^{14} \mathrm{C}$ glycine.

( $S \mu \mathrm{g}$ per hour per $0.5 \mathrm{~g}$ of gills) can be calculated from the initial velocity of the incorporation as follows.

$$
\begin{aligned}
S & =2.27 \times 10^{2} \times 2 \times \frac{1.216 \times 10}{6 \times 10^{6}} \times 3.6 \times 10 \\
& =3.31 \times 10^{-2}
\end{aligned}
$$

The value of $S$ can be regarded as the rate of protein synthesis. Assuming that the gills are in a stationary state, we may apply the method of Sprinson and Rittenberg ${ }^{5)}$ to our data as follows; Let the amount of free intracellular carbons be $P \mu \mathrm{g}$ ( $P$ can be regarded as the amount of carbons in the metabolic pool for protein synthesis), carbons from the breakdown of protein enter the pool at a constant rate $C \mu \mathrm{g}$ per hour and carbons in the pool be consumed for the metabolism other than protein synthesis at a constant rate of $x \mu \mathrm{g}$ per hour, the isotope content of the pool, $I(\mu \mathrm{g})$, at any instant $(t)$ is obtained by integrating

$$
\begin{gathered}
\frac{d I}{I}=-\frac{x+S}{P} d t \\
\text { as } \quad I=I_{0}^{\prime} e^{-(x+S / P) t}
\end{gathered}
$$

where $I_{0}^{\prime}$ is equal to $I$ at $t=0$. Let $I_{t}$ be the amount of isotope incorporated into one $\mathrm{mg}$ of proteins in microgram.

Then

$$
d I_{t}=\frac{I}{P} S d t
$$

is obtained.

From the Equations (2) and (3)

$$
I_{t}=\frac{S}{x+S}-I_{0}^{\prime}\left(1-e^{-(x+S / P) t}\right)
$$

is obtained.

Empirically

$$
I_{t}=A I_{0}\left(1-e^{-B t}\right)
$$

where $I_{0}=$ the amount of isotope added in the medium $(\mu \mathrm{g})$ and $A$ and $B$ are constants.

Comparison of Equation (4) with Equation (5) reveals

$$
x=\frac{I_{0}^{\prime}-A I_{0}}{A I_{0}} S, \quad P=\frac{I_{0}^{\prime}}{I_{0} A B}-S
$$

The time course of the free intracellular ${ }^{14} \mathrm{C}$ is shown in Fig. 2. Extrapolating the time curve to $t=0, I_{0}^{\prime}$ can be obtained as $I_{0}^{\prime}=1.52$ $\times 10^{-2} \mu \mathrm{g} / 0.5 \mathrm{~g}$-gill.

From Equations (1) and (5)

$$
A=1.155 \times 10^{-4} \text { and } B=0.525\left(h^{-1}\right)
$$

is obtained.

Consequently, we can find

$$
\begin{aligned}
x & =\frac{\left(1.52 \times 10^{-2}-1.155 \times 1.098 \times 10^{-4}\right)}{1.155 \times 1.098 \times 10^{-4}} \\
& \times 3.31 \times 10^{-2} \\
& =3.94 \mu \mathrm{g}-\mathrm{C} / \mathrm{h} / \mathbf{0} .5 \text { g-gill }
\end{aligned}
$$

and

$$
\begin{aligned}
P & =\frac{1.52 \times 3.31 \times 10^{-4}}{1.098 \times 1.155 \times 5.25 \times 10^{-5}} \\
& =7.56 \mu \mathrm{g}-\mathrm{C} / 0.5 \mathrm{~g} \text { gill }
\end{aligned}
$$

2.2 Time course of ${ }^{14} \mathrm{C}$-orotic acid uptake by RNA in vitro

From the result given in Table 3 , the incorporation of ${ }^{14} \mathrm{C}$ into RNA can be represented by Equation (6) for at least 4 hour incubation.

$$
I_{t}=-6.93 \times 10^{-6} t^{2}+8.39 \times 10^{-5} t
$$

where $I_{t}=\mu \mathrm{g}$ of ${ }^{14} \mathrm{C}$ incorporated into one $\mathrm{mg}$ of RNA after $t$ hour incubation of gills with ${ }^{14} \mathrm{C}$-orotic acid. 
Table 3 The incorporation of ${ }^{14} \mathrm{C}$-orotic acid into gill RNA

\begin{tabular}{c|c|c}
\hline $\begin{array}{c}\text { Incubation } \\
\text { period (h) }\end{array}$ & \multicolumn{2}{|c}{ Incorporation } \\
\hline 1 & cpm/mg-RNA & $\mu_{\mathrm{gg}}{ }^{14} \mathrm{C} / \mathrm{mg}$-RNA \\
\hline 2 & 374 & $6.84 \times 10^{-5}$ \\
3 & 770 & $1.41 \times 10^{-4}$ \\
4 & 1,080 & $1.97 \times 10^{-4}$ \\
\hline
\end{tabular}

Table 4 RNA content of gill

\begin{tabular}{cc}
\hline $\mathrm{mg}$ of RNA-P per $\mathrm{g}$ of gill \\
0.260 \\
0.261 \\
0.236 \\
0.258 \\
0.254 \\
Mean & 0.254 \\
\hline
\end{tabular}

Since one $\mathrm{g}$ of gills contains $0.254 \mathrm{mg}$ of RNA-P as shown in Table 4, and phosphorus content of the RNA was found to be $8.5 \%$, one $\mathrm{g}$ of gills contains $2.99 \mathrm{mg}$ of RNA. The amount of carbons consumed in the cells for RNA synthesis ( $S \mu \mathrm{g}$ per hour per one $\mathrm{g}$ of gills) can be calculated as follows.

$$
\begin{aligned}
S & =3.74 \times 2.33 \times 2.99 \times 10^{-4} \\
& =2.61 \times 10^{-3}
\end{aligned}
$$

The amount of isotope incorporated into one $\mathrm{mg}$ of RNA in microgram can be described by Equation (4). In Equation (4), while value of $t$ is small, we can write

$$
e^{-(x+S / P) t}=1-\frac{x+S}{P} t+\frac{(x+S)^{2}}{2 P^{2}} t^{2}
$$

Then Equation (4) can be transformed as follows:

$$
I_{t}=-\frac{S(x+S)}{2 P^{2}} I_{0}^{\prime} t^{2}+\frac{S}{P} I_{0}^{\prime} t
$$

Empirically

$$
I_{t}=A t^{2}+B t
$$

is found, where $A$ and $B$ are constants.

Comparison of Equation (7) with Equation (8) reveals

$$
x=-S\left(1+\frac{2 A I_{0}^{\prime}}{B^{2}}\right), \quad P=\frac{S I_{0}^{\prime}}{B}
$$

The time course of the free intracellular ${ }^{14} \mathrm{C}$ is shown in Fig. 3. Extrapolating the time curve to $t=0, I_{0}^{\prime}$ can be obtained as $I_{0}^{\prime}=3.08$

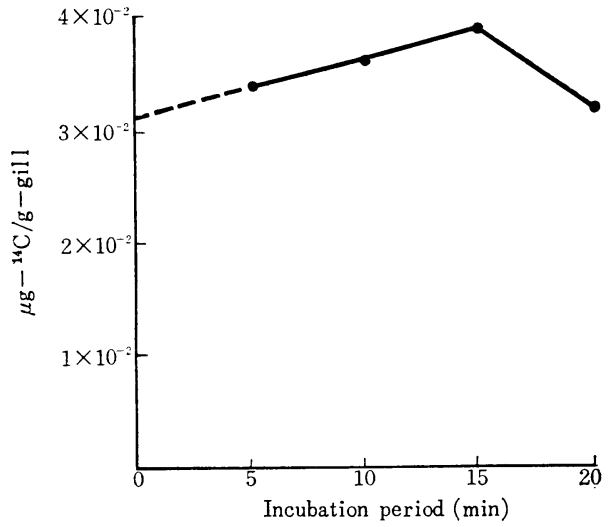

Fig. 3 Time curve of free intracellular ${ }^{14} \mathrm{C}$ content of the gill incubated with ${ }^{14} \mathrm{C}$. orotic acid.

$\times 10^{-2} \mu \mathrm{g}$ /g-gill.

From Equations (6) and (8)

$$
A=-6.93 \times 10^{-6}\left(\mu \mathrm{g}-{ }^{14} \mathrm{C} / \mathrm{h}^{2}\right)
$$

and $B=8.39 \times 10^{-5}\left(\mu \mathrm{g}-{ }^{14} \mathrm{C} / \mathrm{h}\right)$

are obtained.

Consequetly we can find

$$
x=1.32 \times 10^{-2} \mu \mathrm{g}-\mathrm{C} / \mathrm{h} / \mathrm{g} \text {-gill }
$$

and $\quad P=9.85 \times 10^{-1} \mu \mathrm{g}-\mathrm{C} / \mathrm{h} / \mathrm{g}$-gill

2.3 Time course of ${ }^{14} \mathrm{C}$-leucine uptake by proteins in vivo

${ }^{14} \mathrm{C}$-Leucine was injected to adductor muscle and plotting the logarithm of the specific activity of gill-and midgut-proteins vs. time, straight lines were obtained 2 days after injection (Fig. 4). From the slopes of the

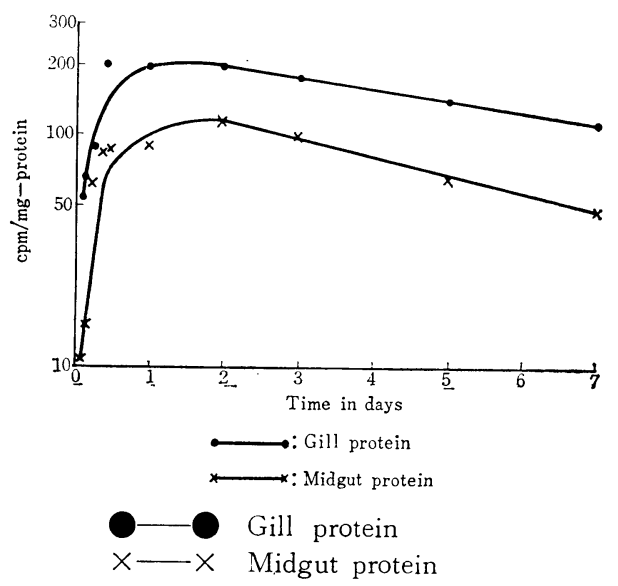

Fig. 4 Specific activities of the gill-and midgutproteins at various time intervals after the injection of ${ }^{14} \mathrm{C}$-L-leucine. 


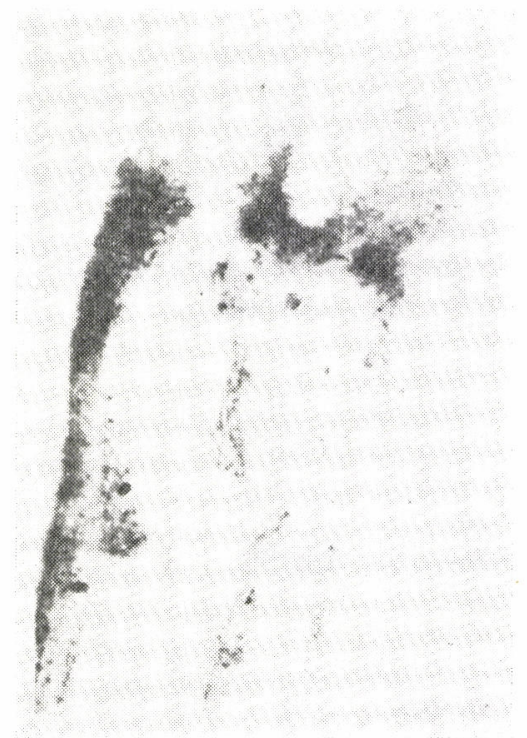

Fig. 5 Autoradiogram of the gill of Mytilus injected with ${ }^{14} \mathrm{C}$-L-leucine (longitudinal section).

straight lines, the half life times $\left(t_{1 / 2}\right)$ are calculated to be 5.8 days for gill-proteins and 3.96 days for midgut-proteins. In the case of gills, a high incorporation of ${ }^{14} \mathrm{C}$ was found in the proteins about mucus glands inside of a ciliated groove as shown in Fig. 5 .

2.4 Time course of ${ }^{14} \mathrm{C}$-orotic acid uptake by RNA in vivo

By plotting the logarithm of the specific

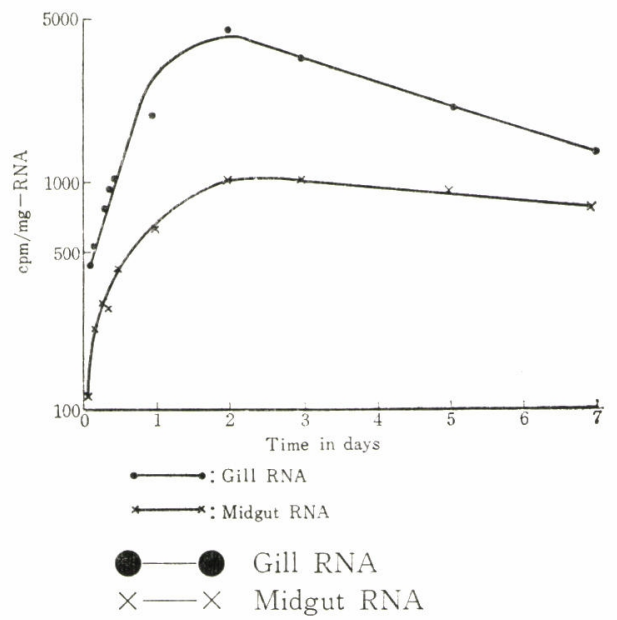

Fig. 6 Specific activities of the gill-and midgutRNAs at various time intervals after the injection of ${ }^{14} \mathrm{C}$-orotic acid. activity of gill-and midgut-RNAs of ${ }^{14} \mathrm{C}$-injected Mytilus vs. time, the straight lines were obtained 3 days after injection (Fig. 6). From the slopes of the straight lines the half life times are calculated to be 2.6 days for gillRNA and 10.6 days for midgut-RNA.

\section{Discussion}

In in vivo experiment, the results may be dependent on the rate of transportation of labeled compound to the organ concerned and the permeability to the labeled compound of the cell in which protein or RNA synthesis is situated. There are many examples that the biosynthesis of a compound from simple substances is often difficultly carried out in slices or homogenates of tissues or organs even when the compound can be easily synthesized from simple substances in an intact animal body. As the gills can be used only cutting it off from an animal, the experimental results on excised gills may be similar to those of in vivo experiment but normal metabolism can continue for only a short period, as nutritional substances are not supplied to gills. In in vitro experiments, the rate of carbon consumption for the metabolism other than protein synthesis has been obtained as $3.94 \mu \mathrm{g} / \mathrm{h} / 0.5$ g-gill. Previously we have found that 3.05 $\mu \mathrm{g}$ of carbons are expired per hour per $0.5 \mathrm{~g}$ of gills in respiration ${ }^{4}$. Thus, $3.94-3.05=0.89$ $\mu \mathrm{g}$ of carbon per hour per $0.5 \mathrm{~g}$ of gills is consumed for glyconeogenesis etc

In in vivo experiments the half life time of gill-protein is found to be 5.8 days. The turnover rate $(k)$ can be calculated from Equation (9).

$$
\begin{aligned}
& k t_{1 / 2}=\ln 2=0.693 \\
& k=\frac{0.693}{5.8}=1.19 \times 10^{-1}\left(\mathrm{day}^{-1}\right)
\end{aligned}
$$

As one $\mathrm{g}$ of gills contains $37 \mathrm{mg}$ of carbons, the daily rate of protein synthesis, the replacement rate, is

$$
37 \times 0.119=4.40 \mu \mathrm{g}-\mathrm{C} / \mathrm{g}-\mathrm{gill} \text {. }
$$

It was previously reported that the active loci of glycogen metabolism of gills were intracellular spaces abutting on the ciliated cells inside of a ciliated groove ${ }^{4)}$. In the case of gill-proteins, the proteins about mucus 
glands inside of a ciliated groove were active metabolically.

The half life time of gill-RNA has been found to be 2.6 days. Thus, $k$ for gill RNA is calculated to be $2.67 \times 10^{-1}\left(\right.$ day $\left.^{-1}\right)$.

\section{References}

1) Gray, J.: Proc. Roy. Soc., 96B,95 (1924)
2) Usuki, I.: Sci. Rep. Tohoku Univ., Ser. IV (Biol.), 28, 53 (1962)

3) Usuki, I.: Sci. Rep. Tohoku Univ., Ser. IV (Biol.), 28, 59 (1962)

4) Schimizu, T. and Taguchi, K.: Radioisotopes, 13, 122 (1964)

5) Sprinson, D.B. and Rittenberg, D.: J.Biol. Chem., 180, 715 (1949)

要旨

\section{イ貝のエラのタンパクおよび RNA 代謝の研究}

田口賢三, 清水泰二

新潟大学放射性同位元素中央研究室

RIを用いてイ貝のエラのタンパクおよでRNAの代謝を追及し，タンパク合成に対するプール中 の炭素量はエラ $0.5 \mathrm{~g}$ あたり $7.56 \mu \mathrm{g}$ であり, この5ち $3.94 \mu \mathrm{g} / \mathrm{h}$ はタンパク合成以外に消費され

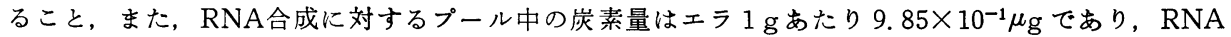
合成以外に消費される炭素量は $1.32 \times 10^{-2} \mu \mathrm{g} / \mathrm{h}$ であることが算出された。さらにin vivo の実験 から，エラおよび中腸腺タンパクの半隇期はそれぞれ 5.8 日, 3.96日で, このときェラの場合, 七 ン毛溝内の粘液腺近辺のタンパクがとくに代謝が活性であることがオートラジオグラフィから知ら れた。RNAの半減期は土ラで2.6日，中腸腺で10.6日であった。 